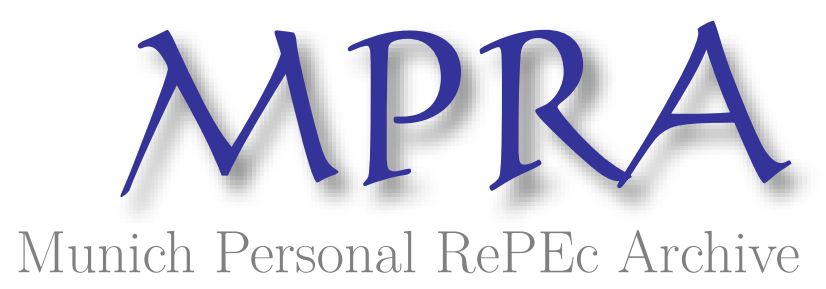

\title{
Onshore and offshore market for Indian Rupee: recent evidence on volatility and shock spillover
}

Behera, Harendra

Reserve Bank of India

January 2010

Online at https://mpra.ub.uni-muenchen.de/22247/

MPRA Paper No. 22247, posted 21 Apr 2010 21:53 UTC 


\title{
Onshore and Offshore Market for Indian Rupee: Recent Evidence on Volatility and Shock Spillover
}

\author{
Harendra Kumar Behera ${ }^{\#}$
}

\begin{abstract}
The paper empirically examines the onshore-offshore linkages of the Indian rupee using recently developed multivariate GARCH techniques. The empirical results show that offshore non deliverable forward (NDF) market does not have mean spillover impact on onshore spot, forward and futures market while shocks and volatilities in NDF market influence the onshore markets. The magnitude of volatility spillover from NDF to spot market, which was lower earlier, became higher after the introduction of currency futures in India. This is probably due to the fact that large arbitrage had taken place between futures and NDF market in recent past. Hence, the study suggests the close monitoring of both the onshore and offshore markets.
\end{abstract}

JEL Classification: G13, F31, C51

Key words: Non deliverable forward, volatility spillover, multivariate GARCH.

\footnotetext{
* The views expressed in the paper are of the author and have no bearing on the organization to which the author belongs.

${ }^{\#}$ Harendra Behera is a Research Officer in the Division of International Finance, Department of Economic Analysis and Policy, Reserve Bank of India, Fort, Mumbai 400001. Email: hbehera@rbi.org.in.
} 


\section{Onshore and Offshore Market for Indian Rupee: Recent Evidence on Volatility and Shock Spillover}

\section{Introduction:}

Non-deliverable forward (NDF) market for emerging market currencies has grown over the years where participation of the non-residents in the onshore market is not possible or limited. The growing activities in NDF market, generally traded in an offshore centre, may have spillover impact on onshore market through the common players in both the onshore and offshore market. Thus, the importance of NDF market can not be simply overlooked because of its trading takes place in the offshore market. The understanding of the behaviour of NDF market is essential for a country to make a successful exchange rate policy. The origin of NDF market is dated back to about two decades old when the emerging market economies (EMEs) started receiving large capital inflows with the liberalization of their capital account. During those days, some EMEs did not have developed domestic forward markets while others had restrictions on non-residents' access to domestic forward market. This is essentially due to the fear of the local monetary authorities that easy access to onshore local currency loans and deposits could encourage speculative financial movements, greater exchange rate volatility, and ultimately some loss of monetary control (Higgins and Humpage, 2005). Consequently, some international banks, starting from the early 1990s, began offering non-deliverable forward contracts to investors to hedge their exposures in EME currencies. As a result, an offshore trading of the currencies having partial control on capital account transactions have evolved over time mainly in two regions, viz. Latin America and Asia. The first phase of expansion of trading activities in NDF market ended with the Asian crisis of 1997 and liquidity had come down significantly thereafter. 
The buoyant growth and upbeat investment climate in the EMEs and the massive shift of manufacturing to low-cost countries such as China and India have led to further increase in demand for trading in emerging market currencies. Along with the increasing economic interest in EMEs, foreign exchange convertibility restrictions in these economies have led to the strengthening of the offshore foreign exchange market. With non-existence of a natural forward market for non-domestic players, private companies and investors investing in these EMEs, non deliverable forwards have become popular derivative instruments catering to the offshore investors' demand for hedging. Notwithstanding this, NDF also provides domestic market participants having overseas presence to take arbitrage opportunities between the offshore and onshore market. As a result, it is possible to have volatility spillover from offshore to onshore market. A similar kind of situation has been observed in certain circumstances when the difference between the NDF and futures rate of the Indian rupee of same maturities reached one rupee, which in turn led the Indian rupee to depreciate sharply. Against this background, the paper is attempting to examine the dynamic relationship between the offshore and onshore market for Indian rupee. . Particularly, the paper attempts to see whether there are any change in the relationship between spot, forward and NDF market after introduction of currency futures in India. The following section provides a brief overview of NDF market. A review of literature on the behaviour of NDF market is presented in Section II. Section III then, discusses the present state of NDF market for Indian rupee. The methodology adopted in this paper to study the onshore-offshore linkages of the Indian rupee is discussed in Section IV. The empirical results are presented in Section V. The final section deals with the concluding remarks of the present study. 


\section{A Brief Overview of NDF Market}

NDFs are types of derivatives for trading in non-convertible or restricted currencies without delivery of the underlying currency where physical delivery is not possible. In an NDF contract, generally two parties agree to a cash payment from one party to another at a future date based on the price on that day of some underlying asset as compared to a contractually agreed future price for the same asset. Thus, the cash-flow is based on the netted difference between the futures spot price (for example, the RBI reference rate in the Indian case) and the contractual price (Rupee NDF rate). Generally, the differential amount is settled in a convertible currency like US dollar. Thus, the risk on the movement of nonconvertible currency is mitigated through the transactions of the differential amount in the offshore market. With increase in capital flows and trade flows of the EMEs, the activity in NDF market for these currencies has increased significantly. Today, there exists a large and increasingly active market in NDFs for many Latin American, East Asian and Eastern European currencies, with centers in Hong Kong, Singapore, South Korea, Taiwan, Japan, London (for Eastern European currencies and Asian currencies) and New York (for Latin American currencies).

As mentioned earlier, the activities in the NDF market increased significantly in the last few years with the increase in capital flows and trade flows of the EMEs ${ }^{1}$. Since NDFs are traded over the counter, it is difficult to obtain data on NDF trading volume. However, a few agencies conduct surveys to report the data on NDF turnover. The Tokyo Foreign Exchange Market Committee conducts regular survey on forex turnover wherein they report detailed data on NDF transactions in Tokyo. According to their survey, the average daily

\footnotetext{
1 Apart from the demand from the investors and traders, the initiatives taken by the EMTA (the trade association for the emerging markets), the New York Foreign Exchange Market Committee, the Bank of England's Foreign Exchange Joint Standing Committee, Tokyo Foreign Exchange Market Committee and Singapore Foreign Exchange Market Committee for simplifying NDF confirmation process, standardizing documentation, and moving the NDF market towards automation has also helped in augmenting liquidity in the NDF market.
} 
NDF turnover, which had increased to US\$ 54.4 billion in April 2007 came down to US\$ 49.8 billion in April 2008 and further to US\$ 7.7 billion in April 2009 (Table 1). The sharp decline in NDF turnover in 2009 was mainly due to deterioration in financial market conditions led by global financial crisis. However, the turnover is still significant and in line with the data reported by other agencies like Duetche Bank. The anecdotal evidence also shows that the activities in NDF market further picked up with the recovery of the financial market after the first half of 2009. Thus, NDFs are becoming more and more popular, allowing banks to offer more liquidity and better client service to their corporate and institutional clients, in more exotic currencies.

Table-1: Average Daily NDF Turnover

(in millions of US dollars)

\begin{tabular}{|c|c|c|c|c|c|c|c|c|}
\hline \multirow[t]{2}{*}{$\begin{array}{l}\text { Sources } \\
\text { of estimates }\end{array}$} & \multirow{2}{*}{$\frac{\text { HSBC }}{(\text { mid-2003) }}$} & \multicolumn{2}{|c|}{ Deutche Bank } & \multicolumn{4}{|c|}{ Tokyo FEMC } & \multirow{2}{*}{$\begin{array}{r}\begin{array}{r}\text { Forwards } \\
\text { and forex } \\
\text { swaps }\end{array} \\
\text { (April } \\
2007) \\
\end{array}$} \\
\hline & & $(2003-04)$ & $(2008-09)$ & $\begin{array}{l}\text { (April } \\
\text { 2006) } \\
\end{array}$ & $\begin{array}{l}\text { (April } \\
2007) \\
\end{array}$ & $\begin{array}{l}\text { (April } \\
2008) \\
\end{array}$ & $\begin{array}{l}\text { (April } \\
2009) \\
\end{array}$ & \\
\hline Chinese renminbi & 1,000 & 50 & 1,000 & 3,200 & 6,761 & 10,074 & 1,737 & 5,650 \\
\hline Indian rupee & 100 & $20-50$ & 800 & 1,400 & 8,685 & 5,439 & 313 & 12,118 \\
\hline Indonesian rupiah & 100 & 50 & 400 & 500 & 1,185 & 2,731 & 228 & 1,852 \\
\hline Korean won & 500 & $700-1,000$ & 3,000 & 9,500 & 25,374 & 9,970 & 3,672 & 18,825 \\
\hline Philippine peso & 50 & $20-30$ & 500 & 1,200 & 1,850 & 2,480 & 239 & 2,176 \\
\hline Malaysian Ringitt & & - & 500 & 500 & 3,233 & 5,938 & 504 & - \\
\hline New Taiwan dollar & 500 & $300-500$ & - & 7,000 & 7,245 & 8,270 & 670 & 6,162 \\
\hline Total & 2,250 & $1,140-1,680$ & 6,200 & & 54,439 & 49,829 & 7,663 & 7,232 \\
\hline
\end{tabular}

\section{Literature on NDF}

The literature on the study of various dynamics of NDF market is rare despite a two decades old market. This is mainly due to the lack of availability of data on NDF rates and turnover as the trade of such instruments takes place over the counter and in an offshore market. To date, there has been very little research conducted studying the behaviour of the 
NDF market ${ }^{2}$. One of the earliest attempts made by Park (2001) is to study the linkages between the South Korean Won spot rate and the NDF rate. Using GARCH framework, he finds evidence of mean and volatility spillover effect from the offshore to onshore market. In later period, many researchers have tried to study NDF market from various aspects. Examining market efficiency of renminbi, Izawa (2005) could not found that renminbi NDF is an unbiased predictor of the future spot rate. Differently, Ma et al. (2004) find positive cross co-movements amongst six Asian NDF currencies than their spot counterparts for the period March 2001 to February 2004. They also showed that, owing to capital restrictions, Asian NDFs are generally not tightly bound by arbitrage to the more controlled spot exchange rates. Consequently, NDF volatilities tend to be higher than the spot rate volatilities (Cairns et al. 2007). Studying cross-market volatility transmission between the Chinese NDF market and seven of its Asia-Pacific counterparts over the period January 1998 to March 2005, Colavecchio and Funke (2006) found that the renminbi NDF has been a driver of various Asian currency markets. Thus, it can be said from the literature that there are interlinkages between various cross-currency NDFs and between onshore exchange rates with offshore NDF rate. It is, therefore, very important for a policy maker in an emerging country to understand the behaviour of the NDF market and possible impact of such market on onshore market. With an objective to study the inter-linkage of Indian rupee (INR) NDF market with onshore spot, forward and future market, the next section provides some stylized facts of INR NDF market.

\section{III.NDF Market for the Indian Rupee}

The authorities in India do not have any control over offshore participation in INR NDF markets. The onshore financial institutions are not allowed to transact in the NDF

\footnotetext{
2 A detail analysis of market structure, behaviour and the evolution of NDF market is provided by Ma, et al. (2004), Lipscomb (2005) and Misra and Behera (2006).
} 
markets. Domestic banking entities are allowed specific open position and gap limits, for their foreign exchange exposures and through these limits domestic entities could play in the NDF markets to take advantage of any arbitrage or even speculate. This itself restricts the extent to which domestic banks could participate in NDF markets. The objective has been that allowing domestic banks to participate in the NDF markets would require an enhanced level of intervention from the Reserve Bank of India (RBI) to protect the Indian rupee from any speculative attack.

However, foreign banks, which operate through different corporate entities in different markets, can be short in the Indian rupee in the domestic market and long in the NDF market at the same time. Besides, corporate entities with an international presence can also undertake speculative or arbitrage trades as long as they satisfy the exchange control guidelines in India. The underlying exposure criteria enables corporates to hedge only a part of their exposures that arise on the basis of the volume of goods (exports/imports) to be delivered. Further, foreign institutional investors and foreign direct investors, who are also allowed in the domestic forward market of India, can influence onshore spot and forward markets because of their presence in offshore market.

The size of the INR NDF market has been increasing over time on the back of (a) large capital and trade flows; (b) larger spread between forward, futures and NDF market; and (c) increasing speculative activities. Though an accurate assessment of the volumes is difficult, estimated daily INR NDF turnover was around US \$ 100 million in 2003/2004 (Ma et al , 2004) and reportedly NDF volumes have grown substantially in the recent period ${ }^{3}$. While these volumes are not large enough to affect the domestic onshore market under regular market conditions, in volatile market conditions, however, they may impact the

\footnotetext{
${ }^{3}$ See also Table 1.
} 
domestic spot markets. According to Misra and Behera (2006), the price discovery in INR NDF market takes place drawing information from onshore market; however, the volatility in NDF markets could influence the onshore markets.

Figure 1 shows that there are large differences between INR NDF rates and other INR rates (forwards and futures) in some occasions. The wide spread between onshore and offshore market encourages market players to take arbitrage advantage. The large spread between INR NDF rate and INR futures/forward rate can influence the spot rates significantly. It can also be observed from the figure that the INR forward rate is influenced by the movement of INR NDF, futures and spot rates with some lag. As found by Misra and Behera (2006), there are volatility spillovers from NDF market to spot and forward market. Whether the findings still hold after the introduction of currency futures in India needs to be examined as the understanding of onshore-offshore link of the rupee would be helpful for protecting the currency from any speculative attack.

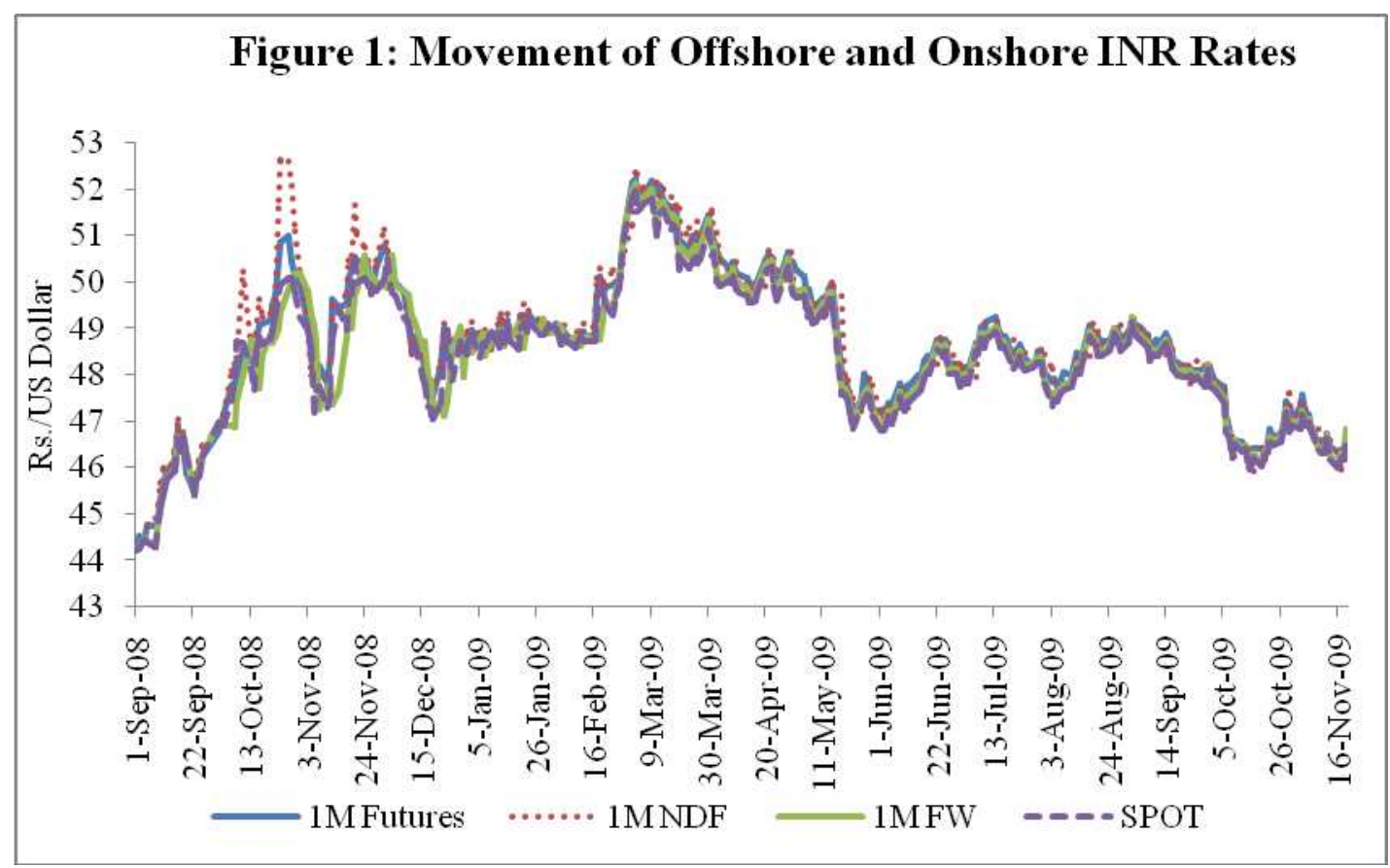




\section{IV.Methodology}

To examine the onshore and offshore relationship of Indian rupee, the multivariate generalized autoregressive conditional heteroscedasticity (MGARCH) model in vector autoegressive (VAR) framework is employed where the conditional mean and variance equations are estimated simultaneously. The MGARCH model used in this paper to study the mean and volatility spillover between onshore and offshore market is the BEKK parameterization of MGARCH, a version proposed by Engle and Kroner (1995). The BEKK model doesn't impose restriction of constant correlation among variables over time. Further, the model incorporates quadratic forms in such a way that ensures the positive semidefiniteness of the covariance matrix ${ }^{4}$. The study, specifically, uses a trivariate GARCH model which allows to study the volatility transmission among three different markets simultaneously.

The mean equation in the VAR-MGARCH model can be specified as:

$$
R_{i, t}=\mu_{i}+\alpha R_{i, t-1}+\varepsilon_{i t}
$$

can also be stated as:

$$
\left[\begin{array}{l}
R_{1, t} \\
R_{2, t} \\
R_{3, t}
\end{array}\right]=\left[\begin{array}{l}
\mu_{1} \\
\mu_{2} \\
\mu_{3}
\end{array}\right]+\left[\begin{array}{lll}
\alpha_{11} & \alpha_{12} & \alpha_{13} \\
\alpha_{21} & \alpha_{22} & \alpha_{23} \\
\alpha_{31} & \alpha_{32} & \alpha_{33}
\end{array}\right]\left[\begin{array}{l}
R_{1, t-1} \\
R_{2, t-1} \\
R_{3, t-1}
\end{array}\right]+\left[\begin{array}{l}
\varepsilon_{1, t} \\
\varepsilon_{2, t} \\
\varepsilon_{3, t}
\end{array}\right]
$$

where $R_{i, t}$ is the return on rupee-dollar exchange rate of the market $i$ (spot, forward, futures or $\mathrm{NDF}$ ) between time $\mathrm{t}$ and $\mathrm{t}-1 ; \mu_{i}$ is the drift coefficient; and $\varepsilon_{i t}$ is the error term for the return on $i^{\text {th }}$ market exchange rate; $\left.\varepsilon_{t}\right|_{t-1} \sim \mathrm{N}\left(0, \mathrm{H}_{\mathrm{t}}\right) ; H_{t}$ is a $3 \times 3$ corresponding variance-

\footnotetext{
4 BEKK model is superior than VECH model as the VECH is based on positive definiteness of covariance matrix, which may not be achieved in many cases. Further, the number of parameters in the VECH model is so large that they are difficult to interpret.
} 
covariance matrix, $I_{t-1}$ is a information set at time $t-1$. The parameter $\alpha_{i j}$ represents the mean spillover effects from market $j$ to market $i$ whereas the $\alpha_{i i}$ measures their own lagged response.

The BEKK parameterization for variance equation can be given as:

$$
H_{t+1}=C^{\prime} C+A^{\prime} \varepsilon_{t} \varepsilon_{t}^{\prime} A+B^{\prime} H_{t} B
$$

The individual elements for C, A and B matrices in Eq. (2) are written as follows:

$$
A=\left[\begin{array}{lll}
a_{11} & a_{12} & a_{13} \\
a_{21} & a_{22} & a_{23} \\
a_{31} & a_{32} & a_{33}
\end{array}\right] \quad B=\left[\begin{array}{lll}
b_{11} & b_{12} & b_{13} \\
b_{21} & b_{22} & b_{23} \\
b_{31} & b_{32} & b_{33}
\end{array}\right] \quad C=\left[\begin{array}{ccc}
c_{11} & 0 & 0 \\
c_{21} & c_{22} & 0 \\
c_{31} & c_{32} & c_{33}
\end{array}\right]
$$

where $\mathrm{C}$ is restricted to be a $3 \times 3$ lower triangular matrix with six parameters. $\mathrm{A}$ is a $3 \times 3$ square matrix of parameters and shows how conditional variances are correlated with past squared errors. The elements $a_{i j}$ measure the effects of shocks spillover from market $j$ to volatility in market $i$ and $a_{i i}$ measure the magnitude of impact of shocks in market $i$ on its own volatility. $\mathrm{B}$ is also a $3 \times 3$ square matrix of parameters and shows how past conditional variances affect current levels of conditional variances. Thus, $b_{i j}$ implies the volatility spillover from market $j$ to market $i$ and $b_{i i}$ indicates persistence of volatility within the same market. The total number of estimated elements for the variance equations for the trivariate BEKK model used in this study is 24 .

To have a better understanding about the effect of shocks and volatility on the conditional variance, the variance equation ignoring the constant terms, can be expanded for the trivariate $\mathrm{GARCH}(1,1)$ as: 


$$
\begin{aligned}
& h_{11, t+1}=a_{11}^{2} \varepsilon_{1, t}^{2}+2 a_{11} a_{12} \varepsilon_{1, t} \varepsilon_{2, t}+2 a_{11} a_{31} \varepsilon_{1, t} \varepsilon_{3, t}+a_{21}^{2} \varepsilon_{2, t}^{2}+2 a_{21} a_{31} \varepsilon_{2, t} \varepsilon_{3, t}+a_{31}^{2} \varepsilon_{3, t}^{2}+b_{11}^{2} h_{11, t}+ \\
& 2 b_{11} b_{12} h_{12, t}+2 b_{11} b_{31} h_{13, t}+b_{21}^{2} h_{22, t}+2 b_{21} b_{31} h_{23, t}+b_{31}^{2} h_{33, t} \\
& h_{22, t+1}=a_{12}^{2} \varepsilon_{1, t}^{2}+2 a_{12} a_{22} \varepsilon_{1, t} \varepsilon_{2, t}+2 a_{12} a_{32} \varepsilon_{1, t} \varepsilon_{3, t}+a_{22}^{2} \varepsilon_{2, t}^{2}+2 a_{22} a_{32} \varepsilon_{2, t} \varepsilon_{3, t}+a_{32}^{2} \varepsilon_{3, t}^{2}+b_{12}^{2} h_{11, t}+ \\
& 2 b_{12} b_{22} h_{12, t}+2 b_{12} b_{32} h_{13, t}+b_{22}^{2} h_{22, t}+2 b_{22} b_{32} h_{23, t}+b_{32}^{2} h_{33, t} \\
& h_{33, t+1}=a_{13}^{2} \varepsilon_{1, t}^{2}+2 a_{13} a_{23} \varepsilon_{1, t} \varepsilon_{2, t}+2 a_{13} a_{33} \varepsilon_{1, t} \varepsilon_{3, t}+a_{23}^{2} \varepsilon_{2, t}^{2}+2 a_{23} a_{33} \varepsilon_{2, t} \varepsilon_{3, t}+a_{33}^{2} \varepsilon_{3, t}^{2}+b_{13}^{2} h_{11, t}+ \\
& 2 b_{13} b_{23} h_{12, t}+2 b_{13} b_{33} h_{13, t}+b_{23}^{2} h_{22, t}+2 b_{23} b_{33} h_{23, t}+b_{33}^{2} h_{33, t}
\end{aligned}
$$

Eqs. (4), (5) and (6) show how shocks $\left(\varepsilon_{t}\right)$ and volatility $\left(h_{t}\right)$ are transmitted across markets and over time. Since exchange rates of four markets (spot, forward, futures and $\mathrm{NDF}$ ) are used, the transmission mechanism is examined by estimating trivariate GARCH models with various combinations of three exchange rate returns.

The BEKK-MGARCH model is estimated using the maximum likelihood method in which the log-likehood can be written as:

$$
L(\theta)=-T \ln (2 \pi)-\frac{1}{2} \sum\left(\ln \left|H_{t}\right|+\varepsilon_{t}^{\prime} H_{t}^{-1} \varepsilon_{t}\right)
$$

where $\mathrm{T}$ is the number of observations and $\theta$ represents the parameter vector to be estimated.

To obtain the estimates of the parameters, a combination of the standard gradient search algorithm Broyden-Fletcher-Goldfarb-Shanno (BFGS) and simplex algorithm are used.

\section{Data and Empirical Findings}

\section{V.1. Data and Preliminary Statistics}

The data used in this study consists of daily closing exchange rates of rupees per US dollar from November 5, 2000 through November 19, 2009. The data on spot, forward and NDF exchange rates are obtained from Reuters for the full sample period consisting 2405 
observations. However, the data on rupee futures are taken from the National Stock Exchange of India starting from September 1, 2008 till November 19, 2009 for 319 observations, as the rupee futures introduced in India on August 29, 2008. The study is conducted for three different samples to see whether the introduction of currency futures in India have led to any changes in the onshore and offshore relationship of the rupee. Thus, the estimations are conducted for three different data periods - (i) full sample period; (ii) sub-period 1: November 5, 2000 to August 28, 2008; and (iii) sub-period 2: September 1, 2008 through November 19, 2009.

All exchange rates are converted into return series to use in the study. All the returns are found to be stationary. The summary of descriptive statistics of all the exchange rate returns along with the results of Ljung Box (LB) Q-Statistics and Lagrange Multiplier (LM) statistics to test the presence of ARCH effect are reported in Table 2.

Table 2: Descriptive Statistics

\begin{tabular}{lrrrr}
\hline & SPOT & FORWARD & NDF & FUTURES \\
\hline Mean & 0.002 & 0.002 & 0.002 & 0.017 \\
Median & 0.000 & 0.000 & 0.000 & 0.000 \\
Maximum & 2.624 & 2.643 & 4.202 & 2.688 \\
Minimum & -3.550 & -3.594 & -4.001 & -3.299 \\
Std. Dev. & 0.359 & 0.357 & 0.441 & 0.695 \\
Skewness & -0.145 & -0.281 & 0.370 & -0.250 \\
Kurtosis & 14.863 & 14.912 & 17.472 & 6.251 \\
Jarque-Bera & $14105.79^{*}$ & $14244.76^{*}$ & $21032.47^{*}$ & $143.34^{*}$ \\
& $(0.00)^{*}$ & $(0.00)$ & $(0.00)$ & $(0.00)$ \\
R Q $(8)$ & $27.14^{*}$ & $30.01^{*}$ & $30.84^{*}$ & $5.18^{*}$ \\
& $(0.00)$ & $(0.00)$ & $(0.00)$ & $(0.18)$ \\
R Q ${ }^{2}(8)$ & $498.59^{*}$ & $527.21^{*}$ & $760.74^{*}$ & $61.16^{*}$ \\
& $(0.00)$ & $(0.00)$ & $(0.00)$ & $(0.00)$ \\
$Q^{2}(8)$ & $487.24^{*}$ & $512.27^{*}$ & $767.40^{*}$ & $60.221^{*}$ \\
& $(0.00)$ & $(0.00)$ & $(0.00)$ & $(0.00)$ \\
LM (8) & $24.61^{*}$ & $25.96^{*}$ & $22.14^{*}$ & $15.57^{*}$ \\
& $(0.00)$ & $(0.00)$ & $(0.00)$ & $(0.11)$ \\
Observations & 2404 & 2404 & 2404 & 318 \\
\hline
\end{tabular}

Note: R Q and R Q ${ }^{2}$ are the Ljung-Box Q-statistics of return and square of return series, respectively. $\mathrm{Q}^{2}$ is $\mathrm{LB}$ Q-statistics of squared errors in eq.(1) and LM for test of ARCH effect.

All the serial correlation tests are conducted up to lag length 8 .

Figures in brackets below various statistics are the p-values. 
From Table 2, it can be observed that all the returns are leptokurtic, i.e. fat tailed and therefore, the presence of ARCH effect in various return series are checked through LB-Q tests of squared returns and squared errors from eq. (1) up to $8^{\text {th }}$ lag. The LM test is employed to see the serial correlation in the squared errors from eq. (1) to test the ARCH effect. All the tests confirmed the presence of ARCH effect in various return series.

\section{V.2. Empirical Results}

Initially, two trivariate GARCH models are estimated taking a combination of spot, forward and NDF for two different sample periods, i.e. for full sample and sub period 1 consisting data before the introduction of currency futures in India. When Rupee futures are considered in estimation procedure, another two combinations are applied for the sub sample consisting 318 observations for the period of September 1, 2008 to November 19, 2009. The two combinations mainly to study the spillover from NDF to spot, forward and futures exchange rates are - (i) spot, futures and NDF; and (ii) forward, futures and NDF. The estimation results of the trivariate GARCH model with BEKK parameterization for variance equation taking spot, forward and NDF returns are reported in Table 3.

The result in Table 3 shows that the estimates $\alpha_{12}$ and $\alpha_{21}$ in Mean equation are highly significant in both the Panel A and Panel B indicating about bi-directional mean spillover between spot and forward market. However, NDF doesn't have any mean spillover impact on either spot or forward as can be seen from insignificant coefficients $\alpha_{13}$ and $\alpha_{23}$. Further, NDF is influenced by both spot and forward market along with its own lag.

The variance-covariance estimates in Panel A are slightly different from that in Panel B. In both the panels, the coefficients $a_{i i}$ and $b_{i i}$ are significant indicating that future volatility in all the spot, forward and NDF market are influenced by the shocks and 
volatilities in their own market. Before the introduction of currency futures in India, spot and forward market have bi-directional shock transmission as can be observed from significant coefficients $a_{12}$ and $a_{21}$. The coefficient $a_{12}$ became insignificant when considered for full sample period implying that the shocks in forward market could not significantly influence spot market volatility. However, the shocks in spot market continued to influence the volatility in forward market. Further, as can be observed from coefficients $a_{31}$ and $a_{32}$, shocks in spot and forward market do not have any statistically significant impact on the volatility of NDF market before the introduction of currency futures, which became statistically significant when considered for full sample. In both Panel A and B, the coefficients $b_{12}$ and $b_{21}$ are statistically significant indicating the volatility spillover from one market to the other in the case of spot and forward. However, the volatility spillover from forward to spot became insignificant when considered for full sample data. Similarly, both way volatility transmissions exist between spot and NDF market. Being $b_{32}$ significant and $b_{23}$ insignificant, it is clear that there are volatility spillovers from forward market to NDF market but the reverse impact does not exist. It is also important to observe from the coefficient $b_{13}$ in both the panels that the magnitude of volatility spillover from NDF to spot market, which was lower earlier, became higher after the introduction of currency futures in India.

With an objective to see the shock and volatility spillover among spot, forward, futures and NDF market in the period after the introduction of currency futures in India, two trivariate GARCH models were estimated taking the combinations of (i) spot, futures and NDF; and (ii) forward, futures and NDF. The estimates of the coefficients in Mean and Variance equations are given in Table 4. Panel A of the table represents the results for the combination of spot, futures and NDF. It can be observed from the table that spot and futures have bi-directional mean spillover impacts and their mean return is not influenced by NDF 
return. On the other hand, there is mean spillover impact from spot and futures market to NDF market. The coefficient estimates in the variance equation are implying that there exist both shock and volatility spillover among spot, futures and NDF market, except the shock spillover impact from futures to NDF market. Moreover, volatilities in all the markets are influenced by their own previous volatility. As mentioned earlier, the magnitude of volatility spillover from NDF to spot became stronger after the introduction of INR futures in India.

\begin{tabular}{|c|c|c|c|c|c|c|}
\hline \multicolumn{7}{|c|}{ Table 3: Estimated Coefficients of Trivariate GARCH Model } \\
\hline Coefficients & Spot $(i=1)$ & t-Stat & Forward (i=2) & t-Stat & NDF (i=3) & t-Stat \\
\hline \multicolumn{7}{|c|}{ Panel A: Sample period: November 5, 2000 to November 19, 2009} \\
\hline \multicolumn{7}{|c|}{$\begin{array}{l}\text { Mean Equation } \\
\end{array}$} \\
\hline$\alpha_{i 1}$ & $0.202^{*}$ & 3.089 & $0.231^{*}$ & 3.565 & $0.590^{*}$ & 6.064 \\
\hline$\alpha_{i 2}$ & $-0.208^{*}$ & -3.156 & $-0.236^{*}$ & -3.561 & $0.216^{*}$ & 2.207 \\
\hline$\alpha_{i 3}$ & 0.004 & 0.256 & 0.004 & 0.232 & $-0.087^{*}$ & -5.063 \\
\hline \multicolumn{7}{|c|}{ Variance Equation } \\
\hline$a_{i 1}$ & $0.478^{*}$ & 7.045 & $-0.148^{*}$ & -1.925 & $0.035^{*}$ & 2.462 \\
\hline$a_{i 2}$ & 0.082 & 1.250 & $0.243^{*}$ & 3.246 & $0.035^{*}$ & 2.494 \\
\hline$a_{i 3}$ & -0.061 & -0.619 & $0.361^{*}$ & 3.661 & $0.412^{*}$ & 18.477 \\
\hline$b_{i 1}$ & $0.857^{*}$ & 42.974 & $0.102^{*}$ & 5.078 & $-0.038^{*}$ & -7.342 \\
\hline$b_{i 2}$ & $-0.063^{*}$ & -3.309 & $1.023^{*}$ & 53.672 & $-0.037^{*}$ & -7.237 \\
\hline$b_{i 3}$ & $-0.073^{* *}$ & -1.675 & 0.026 & 0.614 & $0.827^{*}$ & 53.442 \\
\hline \multicolumn{7}{|c|}{ Log likelihood: 4755.8} \\
\hline \multicolumn{7}{|c|}{ Panel B: Sample period: November 5, 2000 to August 29, 2008} \\
\hline \multicolumn{7}{|c|}{$\begin{array}{ll}\text { Mean Equation } \\
\end{array}$} \\
\hline$\alpha_{i 1}$ & $0.195^{*}$ & 6.138 & $0.219^{*}$ & 7.761 & $0.631^{*}$ & 6.434 \\
\hline$\alpha_{i 2}$ & $-0.186^{*}$ & -6.068 & $-0.209^{*}$ & -7.298 & $0.171^{* *}$ & 1.727 \\
\hline$\alpha_{i 3}$ & 0.002 & 0.103 & 0.003 & 0.190 & $-0.083^{*}$ & -4.132 \\
\hline \multicolumn{7}{|c|}{ Variance Equation } \\
\hline$a_{i 1}$ & $0.594^{*}$ & 11.774 & $-0.243^{*}$ & -4.453 & 0.007 & 0.391 \\
\hline$a_{i 2}$ & $0.182^{*}$ & 3.950 & $0.160^{*}$ & 3.178 & 0.010 & 0.574 \\
\hline$a_{i 3}$ & 0.022 & 0.213 & $0.311^{*}$ & 3.086 & $0.454^{*}$ & 15.686 \\
\hline$b_{i 1}$ & $0.793^{*}$ & 29.964 & $0.161^{*}$ & 6.313 & $-0.036^{*}$ & -3.427 \\
\hline$b_{i 2}$ & $-0.114^{*}$ & -4.885 & $1.070^{*}$ & 48.390 & $-0.036^{*}$ & -3.491 \\
\hline$b_{i 3}$ & $-0.101^{* *}$ & -1.711 & 0.062 & 1.068 & $0.769^{*}$ & 26.139 \\
\hline \multicolumn{7}{|c|}{ Log likelihood: 4669.6} \\
\hline Note & $*, * *$ indic & $5 \%$ & $10 \%$ level, & vely. & & \\
\hline
\end{tabular}




\begin{tabular}{|c|c|c|c|c|c|c|}
\hline \multicolumn{7}{|c|}{ Table 4: Estimated Coefficients of Trivariate GARCH Model } \\
\hline Coefficients & Spot $(i=1)$ & t-Stat & Futures $(i=2)$ & t-Stat & $\operatorname{NDF}(i=3)$ & t-Stat \\
\hline \multicolumn{7}{|c|}{ Panel A: Sample period: September 1, 2008 to November 19, 2009} \\
\hline \multicolumn{7}{|c|}{ Mean Equation } \\
\hline$\alpha_{i 1}$ & $-0.231^{*}$ & -3.180 & $0.226^{*}$ & 3.732 & $0.470^{*}$ & 8.132 \\
\hline$\alpha_{i 2}$ & $0.250^{*}$ & 3.094 & $-0.218^{*}$ & -3.309 & $0.501^{*}$ & 7.450 \\
\hline$\alpha_{i 3}$ & -0.045 & -0.988 & 0.002 & 0.054 & $-0.113^{*}$ & -4.159 \\
\hline \multicolumn{7}{|c|}{ Variance Equation } \\
\hline$a_{i 1}$ & $-0.262^{*}$ & -2.908 & $0.335^{*}$ & 3.280 & $-0.146^{*}$ & -1.949 \\
\hline$a_{i 2}$ & $-0.254^{*}$ & -3.004 & $0.418^{*}$ & 4.488 & -0.084 & -1.207 \\
\hline$a_{i 3}$ & $-0.497^{*}$ & -8.391 & $0.754^{*}$ & 11.512 & $0.239^{*}$ & 5.084 \\
\hline$b_{i 1}$ & $-0.976^{*}$ & -11.943 & $1.645^{*}$ & 14.017 & $0.275^{* *}$ & 1.752 \\
\hline$b_{i 2}$ & $-1.125^{*}$ & -26.156 & $1.267^{*}$ & 12.385 & $0.745^{*}$ & 6.896 \\
\hline$b_{i 3}$ & $0.620^{*}$ & 9.143 & $-0.492^{*}$ & -5.893 & $0.442^{*}$ & 6.958 \\
\hline \multicolumn{7}{|c|}{ Log likelihood: -598.9} \\
\hline \multicolumn{7}{|c|}{ Panel B: Sample period: September 1, 2008 to November 19, 2009} \\
\hline & Forward $(\mathrm{i}=1)$ & t-Stat & Futures $(\mathrm{i}=2)$ & t-Stat & NDF (i=3) & t-Stat \\
\hline \multicolumn{7}{|c|}{ Mean Equation } \\
\hline$\alpha_{i 1}$ & $-0.255^{*}$ & -2.120 & 0.130 & 1.462 & $0.447^{*}$ & 7.555 \\
\hline$\alpha_{i 2}$ & $0.358^{*}$ & 2.658 & -0.063 & -0.560 & $0.547^{*}$ & 8.319 \\
\hline$\alpha_{i 3}$ & -0.031 & -0.705 & 0.006 & 0.165 & $-0.082^{*}$ & -2.194 \\
\hline \multicolumn{7}{|c|}{ Variance Equation } \\
\hline$a_{i 1}$ & $-0.235^{*}$ & -2.714 & $0.231^{* *}$ & 1.717 & $-0.124^{*}$ & -2.163 \\
\hline$a_{i 2}$ & $-0.375^{*}$ & -4.787 & $0.485^{*}$ & 3.814 & $-0.158^{*}$ & -2.617 \\
\hline$a_{i 3}$ & $-0.556^{*}$ & -9.090 & $0.772^{*}$ & 7.618 & $0.245^{*}$ & 5.188 \\
\hline$b_{i 1}$ & $1.091^{*}$ & 20.679 & $-0.401^{*}$ & -8.657 & $-0.796^{*}$ & -5.748 \\
\hline$b_{i 2}$ & $0.156^{* * *}$ & 1.772 & $0.464^{*}$ & 15.757 & $-1.144^{*}$ & -13.031 \\
\hline$b_{i 3}$ & 0.135 & 1.243 & $-0.499^{*}$ & -7.654 & $-0.304^{*}$ & -2.751 \\
\hline \multicolumn{7}{|c|}{ Log likelihood: -595.9 } \\
\hline
\end{tabular}

Panel B of the table represent the results of trivariate GARCH for forward, futures and NDF market. The results in mean equation show that there are mean spillover from futures to forward and NDF market, and from forward to NDF market. However, futures market does not have any mean spillover impact either from forward or from NDF market. Further, NDF market is impacted by mean spillover in forward market apart from its own. Shocks in forward, futures and NDF markets influence each other as can be observed from the significant coefficients of conditional error terms. Coming to the volatility transmission part, it can be depicted from the table that futures and NDF markets have volatility spillover 
from all the markets. Volatility in forward market is also impacted by the volatility in futures market apart from its own volatility. Forward market volatility is influenced by the volatility in futures market and not by the volatility in the NDF market.

\section{Concluding Observations}

With the growing interest of the global players in the Indian economy and the consequent increase in capital inflows into India over last few years, there has been an increase in activities in the INR NDF market. This market essentially draws information from the spot, forward and futures markets. While the offshore NDF rates do not have mean spillover impact on onshore spot, forward and futures market, shocks and volatilities in NDF markets are empirically found to influence the onshore markets. The magnitude of volatility spillover from NDF to spot market, which was lower earlier, became higher after the introduction of currency futures in India. This is probably due to the fact that large arbitrage has taken place between futures and NDF market in recent past. Further, volatility spillover from NDF market to futures market is also significantly high.

So long as there is differential treatment between residents and non-residents with regard to their operation in derivatives market, offshore INR NDF market will continue to thrive. Till that point, the NDF markets could be regarded as essential for sustenance of offshore investor's interest in the domestic economy. The activity in the NDF market needs to be closely monitored to keep track of the pressures operating on the Indian currency as well as to prevent speculative attack on Indian currency during volatile conditions. Apart from above policy issues, the finding of the study have important implications for currency risk management participating in both offshore and onshore markets. 


\section{Reference:}

Cairns, J., Ho, C.and McCauley, R., 2007, Exchange Rates and Global Volatility: Implications for Asia-Pacific Currencies. BIS Quarterly Review, March.

Colavecchio, R. and Funke, M., 2006, Volatility Transmissions Between Renminbi and Asia-Pacific Onshore and Off-shore U.S. dollar Futures. BOFIT Discussion Papers No. 16, Bank of Finland.

Engle, R. and Kroner, F.K., 1995, Multivariate Simultaneous Generalized ARCH. Econometric Theory 11, 122-150.

Higgins, P. and Humpage, O. F., 2005, Nondeliverable Forwards: Can We Tell Where the Renminbi Is Headed? Federal Reserve Bank of Cleveland, September.

Ishii, S., Otker-Robe, I. and Cui, L., 2001, Measures to Limit the Offshore use of Currencies: Pros and Cons. IMF Working Paper, WP01/43, April.

Izawa, H., 2006, An Empirical Test of the Efficiency Hypothesis on the Renminbi NDF in Hong Kong Market. Discussion Paper Series No. 196, Kobe University, November.

Ma, G., C. Ho and McCauley, R. N., 2004, The markets for Non-Deliverable Forwards in Asian Currencies. BIS Quarterly Review, June.

Misra, S. and Behera, H., 2006, Non Deliverable Foreign Exchange Forward Market: An Overview. Reserve Bank of India Occasional Papers 27, Winter, 25-55.

Park, J., 2001, Information flows between non-deliverable forwards (NDF)/and spot markets: Evidence from Korean currency. Pacific Basin Finance Journal 9, 363-377. 